\title{
Od muzejske zbirke do provedbe zaštite in situ - proces uspostave dizajnerske baštine zagrebačke moderne
}

Ceraj, Iva

Source / Izvornik: Institucije povijesti umjetnosti : zbornik 4. kongresa hrvatskih povjesničara umjetnosti, 2019, 225 - 232

Conference paper / Rad u zborniku

Publication status / Verzija rada: Published version / Objavljena verzija rada (izdavačev PDF)

https://doi.org/10.31664/z4khpu.30

Permanent link / Trajna poveznica: https://urn.nsk.hr/urn:nbn:hr:254:539925

Rights / Prava: Attribution 4.0 International/Imenovanje 4.0 međunarodna

Download date / Datum preuzimanja: 2023-04-26

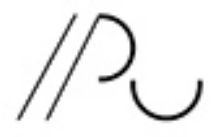

INSIIIUTZZA POVIJESTUMJETNOST
Repository / Repozitorij:

PODEST - Institute of Art History Repository

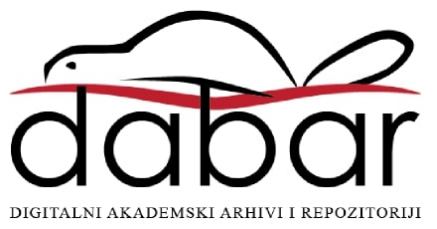




\section{Od muzejske zbirke do provedbe zaštite in situ-proces uspostave dizajnerske baštine zagrebačke moderne}

Poznavanje povijesnih izvora arhitektonske prakse-koje Louis Cardinal, sukladno misiji ICAM-a, ${ }^{1}$ smatra inspirativnim infor-

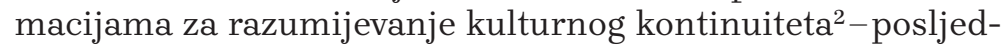
njih godina postaje metodološkom okosnicom proučavanja moderne arhitekture I950-ih i I96o-ih godina. Jačanje interesa za istraživanja arhivskih zbirki arhitekture 20. stoljeća kao referentnih mjesta za stjecanje bogatijih slojeva spoznaje pri valorizaciji arhitektonskih opusa redovito, u duhu sinteze svih likovnih umjetnosti, uključuje i područje interijera te oblikovanje opreme i mobilijara.

Razumijevanje arhitektonskog stvaralaštva ovoga razdoblja nedostatno je dakle bez usmjeravanja istraživačkog fokusa na arhivske fondove kao zbroj djelovanja pojedinog arhitekta, uz neizostavno proučavanje onodobne kritičke recepcije. ${ }^{3} \mathrm{Uz}$ grafičke dokumente-preliminarne skice, crteže i projektnu dokumentaciju-fondovi omogućuju priključenje fotografske i pisane dokumentacije kao vrijednoga kontekstualnog gradiva za razumijevanje transfera utjecaja i formacije ideja. Te klasifikacijske cjeline sastavnice su i Osobnih arhivskih fondova kao integralnih dijelova zbirke Hrvatskoga muzeja arhitekture HAZU. Njihova sustavna obrada podrazumijeva model sinergije kustoskog rada i znanstvene interpretacije, omogućavajući implementaciju rezultata stručnoga bavljenja u znanost, ali i utemeljenije zagovaranje daljih pitanja zaštite baštinskih sadržaja-osobito interijera i pripadnog mobilijara kao krhkih i nadasve ugroženih cjelina.

\section{Muzej bez zidova}

Osobitost koju podrazumijeva zbirka nacionalnog, specijaliziranog muzeja arhitekture jest u povezanosti crteža, skica i projektne dokumentacije pohranjene u čuvaonicama s realizacijom koja se nalazi izvan granica Muzeja-u realnom

\section{Iva Ceraj}

Hrvatski muzej arhitekture Hrvatska akademija znanosti i umjetnosti iceraj@hazu.hr

(D) https://orcid.org/oooo-oooI-5400-3942
I International Confederation of Architectural Museums.

2 LOUIS CARDINAL, Acquisition Principles, Criteria and Methodology, $\mathrm{u}:$ A Guide to the Archival Care of Architectural Records igth-2oth Centuries, (ur.) M. Daniels, D. Peyceré, Pariz, 200o., 42.

3 DAVID PEYCERÉ, Access and Dissemination: Research and Exhibitions (bilj. 2), I22. 


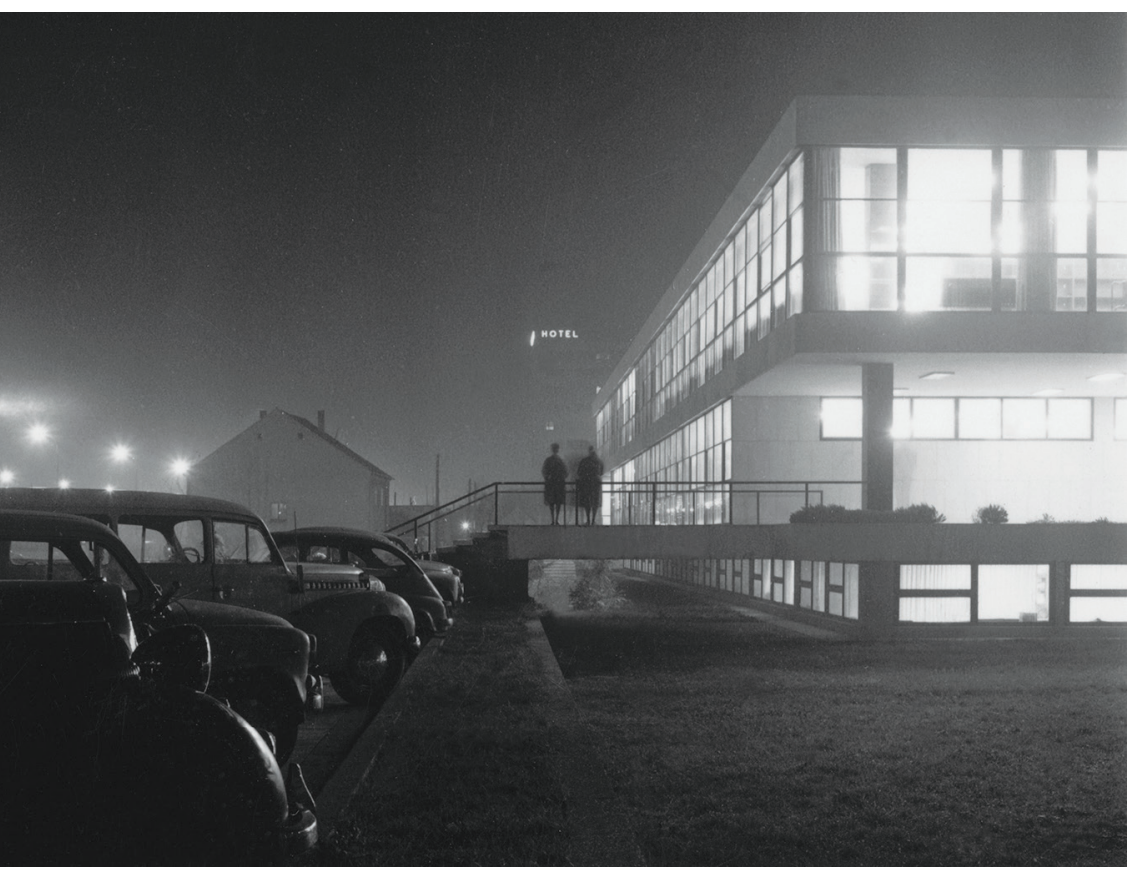

gradskom prostoru ili, u slučaju namještaja, u prostoru interijera. Stoga bi Malrauxov Le Musée imaginaire ovdje mogao značiti muzej bez zidova u smislu produžetka linija izvučenih tušem ili olovkom na paus-papiru u stvarni okoliš. S druge strane, realizirani prostori ili njihova oprema-nekoć predani na korištenje korisnicima i sadržajima za koje su oblikovani-danas mogu postati mjestima kulturne memorije, škole per se o modernoj arhitekturi i oblikovanju.

Jedan je od takvih primjera-danas zanemarenih i velikim dijelom devastiranih-nekadašnje Radničko sveučilište Moša Pijade u Zagrebu (danas: Pučko otvoreno učilište Zagreb), antologijsko zdanje arhitekata Radovana Nikšića i Ninoslava Kučana realizirano I96r. godine (sl. I), a za čiji je interijer ugrađeni i mobilni namještaj oblikovao Bernardo Bernardi kao prvi industrijski dizajner grupe EXAT 5I. Cjelovita grafička dokumentacija ove jedinstvene serije, skladno uklopljene $u$ interijer zgrade, čuva se u Osobnom arhivskom fondu dvojice autora kao osobito vrijednu dijelu muzejske zbirke, dok se izvedeni primjerci namještaja-iako u znatno manjem broju i pretežito lošem stanju-još nalaze in situ: izvornom prostoru za koji su nekoć i oblikovani.

Zahvaljujući toj poveznici, nakon provedene obrade građe, monografske $^{4}$ i izložbene prezentacije ${ }^{5}$ bilo je moguće poduzeti daljnje korake na konkretnom očuvanju i zaštiti te ugrožene serije kao vrhunskog primjera vitalne povezanosti mobilijara s modernim interijerom. U tom je cilju-sukladno preporukama o društveno odgovornoj znanosti-izrađena studija s usporednim stanjem izvornog i zatečenog namještaja u zgradi, a proces izlučivanja originala te saznanja o količini proizvedenih jedinica omogućeni su konzultacijama Bernardijevih bilješki, uz neposredno provedeno terensko istraživanje. ${ }^{6}$

\section{Slika I}

Radovan Nikšić i Ninoslav

Kučan, Radničko sveučilište

Moša Pijade u Zagrebu (dalje: Rs),

sjeverozapadno pročelje, I96I.

foto: Krešimir Tadić, Hrvatski

muzej arhitekture HAZU, Osobni

arhivski fond Radovana Nikšića

(dalje: HMA HAZU, OAF RN)
4 IVA CERAJ, Dizajnersko djelo arhitekta Bernarda Bernardija I95I-I985., Hrvatska akademija znanosti i umjetnosti-Hrvatski muzej arhitekture HAZU (dalje: HMA HAZU), Zagreb, 20I5. [poglavlje „Sintezna točka susreta geometrijskih i organskih značajki moderne-oprema i namještaj za Radničko sveučilište Moša Pijade u Zagrebu", I54-ı88.]

5 Na istoimenoj izložbi (bilj. 4), održanoj 2or6. godine u HMA HAZU (autorica: I. Ceraj), uz nacrte bili su zastupljeni i primjerci originalnog namještaja posuditelja Pučkog otvorenog učilišta Zagreb i Instituta za povijest umjetnosti.

6 Rezultati neposrednog terenskog rada i višemjesečnog dokumentiranja iznose se u: IVA CERAJ, Popis namještaja i opreme za Radničko sveučilište Moša Pijade u Zagrebu, Zagreb, 20I4. [elaborat]. Popisom su obuhvaćene postojeće grupe namještaja u zgradi: oprema za sjedenje, radni stolovi i stolići, ugrađeni i pokretni ormari, radni ormarići, ugrađene police i ploče za pisanje te elementi nekadašnje izložbene konstrukcije. Zaseban inventarni popis obnovljenog namještaja u Institutu za povijest umjetnosti izradila je Ivana Haničar Buljan. 


\section{Povezanost interijera i mobilijara}

Kada je riječ o mobilijaru poslijeratne moderne, valja podsjetiti da njegovi stvaratelji formativno redom proistječu iz Zagrebačkog kruga arhitekture. Kao promicatelji tradicije modernizma, zagovaraju interdisciplinarno razmicanje granica projektnih zadataka s težištem na ostvarenju sinteznog pristupa u kojem svaki detalj imanentno sadržava vrijednost cjeline. Stoga ne čudi da je zgrada Radničkog sveučilišta ubrzo po realizaciji nagrađena, uz obrazloženje o „uspješnoj, široko shvaćenoj koncepciji koju su autori uspjeli ostvariti tako da cjelina, ali i svaki detalj, jasno izražava njihovu kreativnu misao”.7 (sl. 2) Štoviše, naglašeno je „izvrsno rješenje arhitekta Bernardija koji se likovno i funkcionalno uklopio u osnovnu zamisao projekta i pridonio potpunoj likovnoj sintezi."

Stoga preporuku o razumijevanju modernog mobilijara kao vitalnog dijela interijera u duhu total-dizajna već potkrepljuje kritička recepcija razdoblja, kao i činjenica da se I950-ih i I96o-ih godina opremanje javnih arhitektonskih objekata javlja kao najčešći oblik narudžbe, dok pojedinačno oblikovan namještaj još nije redovita pojava. Iz navedenih razloga čini se utemeljenim zagovaranje termina dizajnerske baštine zagrebačke moderne kao nove kategorije kojim bi se osiguralo učinkovitije očuvanje baštinskih sadržaja.

Oblikovne vrijednosti zgrade nekadašnjeg Radničkog sveučilišta tek su jedna od referentnih točaka zagrebačke moderne-mjesta koja, usprkos zapuštenosti, imaju potencijal prijenosa povijesnoumjetničkog znanja. Otkrivanje mogućnosti koje nosi taj sloj značenja tek predstoji kao zadatak, s obzirom da je optika sadašnjega trenutka podešena upravo na prepoznavanje vrijednosti razdoblja I950-ih i I96o-ih godina prošlog stoljeća. Zagovaranjem povezanosti muzeja kao temeljne baštinske ustanove u kojoj se nalazi idejna dokumentacija te pojedinog prostora s mobilijarom kao realizacije te iste ideje, mjesta poput današnjega Pučkog otvorenog učilišta mogla bi postati institucijama pamćenja (memory institutions). Tim pojmom Roland Hjerppe obuhvaća sve kulturne ustanove koje stvaraju zbirke, pa stoga i sponu između znanja (pamćenja) i ljudi. ${ }^{9}$
9 Uvodeći taj generički pojam I994. godine, Hjerppe misli na „kulturne i baštinske ustanove, uključujući knjižnice, muzeje, arhive, spomenike, područja i mjesta (...)" kao stvaratelje zbirki. Termin ponovno aktualizira Lorcan Dempsey u programskom dokumentu za Europsku komisiju 20oo. godine. Usp. MAJA ŠOJAT-BIKIĆ, Modeliranje digitalnih zbirki i digitalnih proizvoda: sadržajno-korisnički aspekt komuniciranja kulturne baštine $\mathrm{u}$ digitalnom obliku, $\mathrm{u}$ : Muzeologija, Zagreb, 50 (20I3.), 6I-62.

Slika 2

Radovan Nikšić, rukopisne bilješke o interijeru RS, I985. HMA HAZU, OAF RN

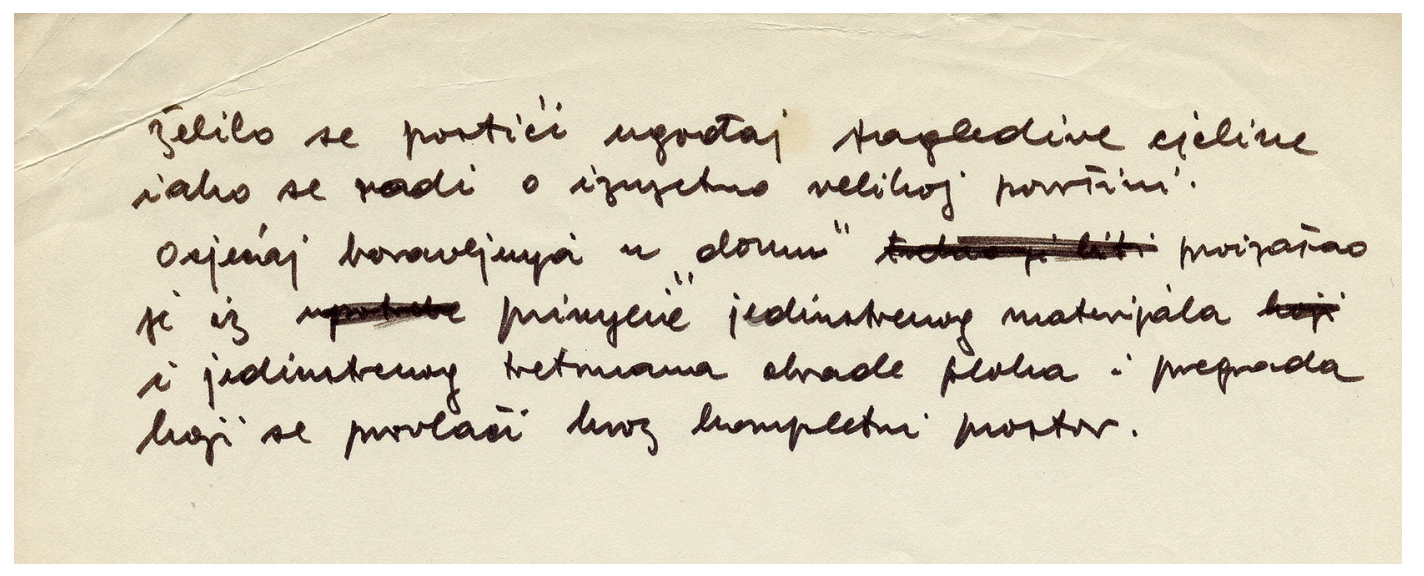




\section{Prostor kao (pre)nositelj kulturne memorije}

U slučaju Radničkog sveučilišta prostor se pokazuje kao nositelj kulturne memorije dvaju moderniteta: idejne baštine pokreta De Stijl prisutne u arhitektonici te organskog modernizma nordijske provenijencije u oblikovnom slogu mobilijara. Rješenje je već u projektnom zadatku predstavljalo vrhunsko ostvarenje space-time ideje $\mathrm{e}^{10}$ - prostora bez rubova ili kontinuiranog prostora (sl. 3), u kojem susret dvaju autora „nije mogao biti sretniji”; , gotovo vršnjaci, kolege na fakultetu, zaljubljenici u neoplasticizam", ${ }^{11}$ Nikšić i Bernardi po svome su intelektualnom habitusu dijelili isti kreativni program, što je uostalom i rezultiralo skladnim nadovezivanjem arhitekture i dizajna pod jednim krovom. Nikšić je estetiku čistih euklidovskih formi, na tragu zagrebačke tradicije i internacionalnog stila, pročistio iskustvom studijskog boravka u Nizozemskoj 1956. godine, gdje u roterdamskom atelijeru Joa H. van den Broeka i Jacoba B. Bakeme iz prve ruke upoznaje Oudov i Rietveldov asketski idiom.

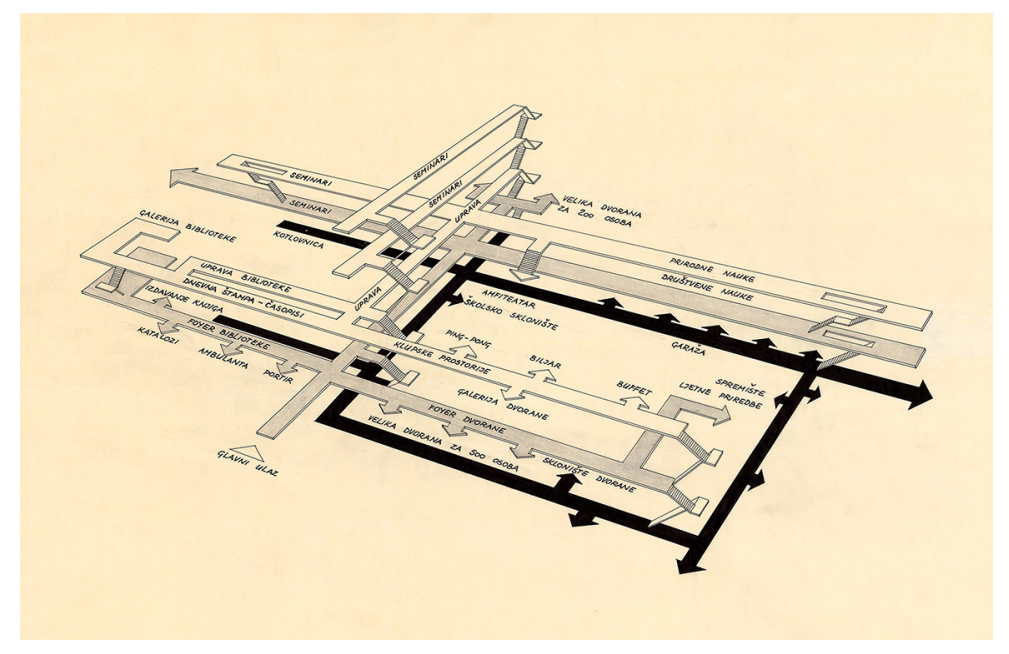

Usmjerenost na izričaj svojstven pravcu De Stijl Bernardijev mobilijar pratit će do mjere zaključenja ideje: primjerice, kolorističkim akcentima naslonjača, čistih kubusa žarkocrvene boje (sl. 4, 5), ali i u koracima daljeg obogaćenja asketske funkcionalnosti sjedalica mekim linijama organskog sloga $($ sl. 6,7$)$ na tragu Arne Jacobsena, Hansa J. Wegnera ili Finn Juhla, čiji rad upoznaje ig6o. godine za vrijeme studijskog boravka u nordijskim zemljama. Stoga su na ovome zadatku-podjednako Nikšić u arhitekturi, kao i Bernardi u dizajnu-dokazali status modernih klasika, zbog čega to sintezno djelo i danas, usprkos pretrpljenim devastacijama, zrači aktualnošću i ljepotom. ${ }^{12}$

Time se otvaraju dodatna pitanja: primjerice, kako u sadašnjem trenutku, koji bilježi nov interes za otkrivanje vrijednosti razdoblja moderne, omogućiti prostorima interijera i njegove opreme komuniciranje kulturne memorije. Zanimljivo je u
Io Usp. s naslovom djela: SIGFRIED GIEDION, Space, Time and Architecture: The Growth of a New Tradition, Cambridge, I94I.

II ZDENKO TONKOVIĆ, Radovan Nikšić: vitalnost moderniteta, u: Radovan Nikšić I920.-I987: arhiv arhitekta, (ur.) D. Kisić, Zagreb, 2005., 35.

I2 Ostvarene vrijednosti mogu se doživjeti „tek kretanjem u stvarnim prostorima, jer teško je dočarati riječima, pa i fotografijama, ljepotu ove zgrade", RADOVAN IVANČEVIĆ, Nova zgrada Radničkog sveučilišta Moša Pijade, u: I5 dana, Zagreb, I (ı96ı.), 9.
Slika 3

Radovan Nikšić, komunikacijska shema RS, I956. HMA HAZU, OAF RN 


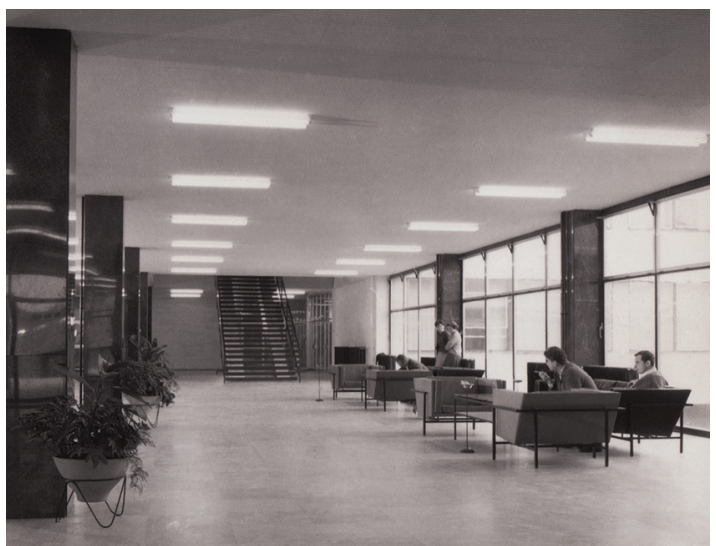

Slika 4

Ulazni hol u

prizemlju RS, I96I.

foto: Željko Krčadinac,

HMA HAZU, OAF RN

Slika 5

Bernardo Bernardi, naslonjač A6, I96I.

HMA HAZU, Osobn

arhivski fond

Bernarda Bernardija

(dalje: OAF BB)
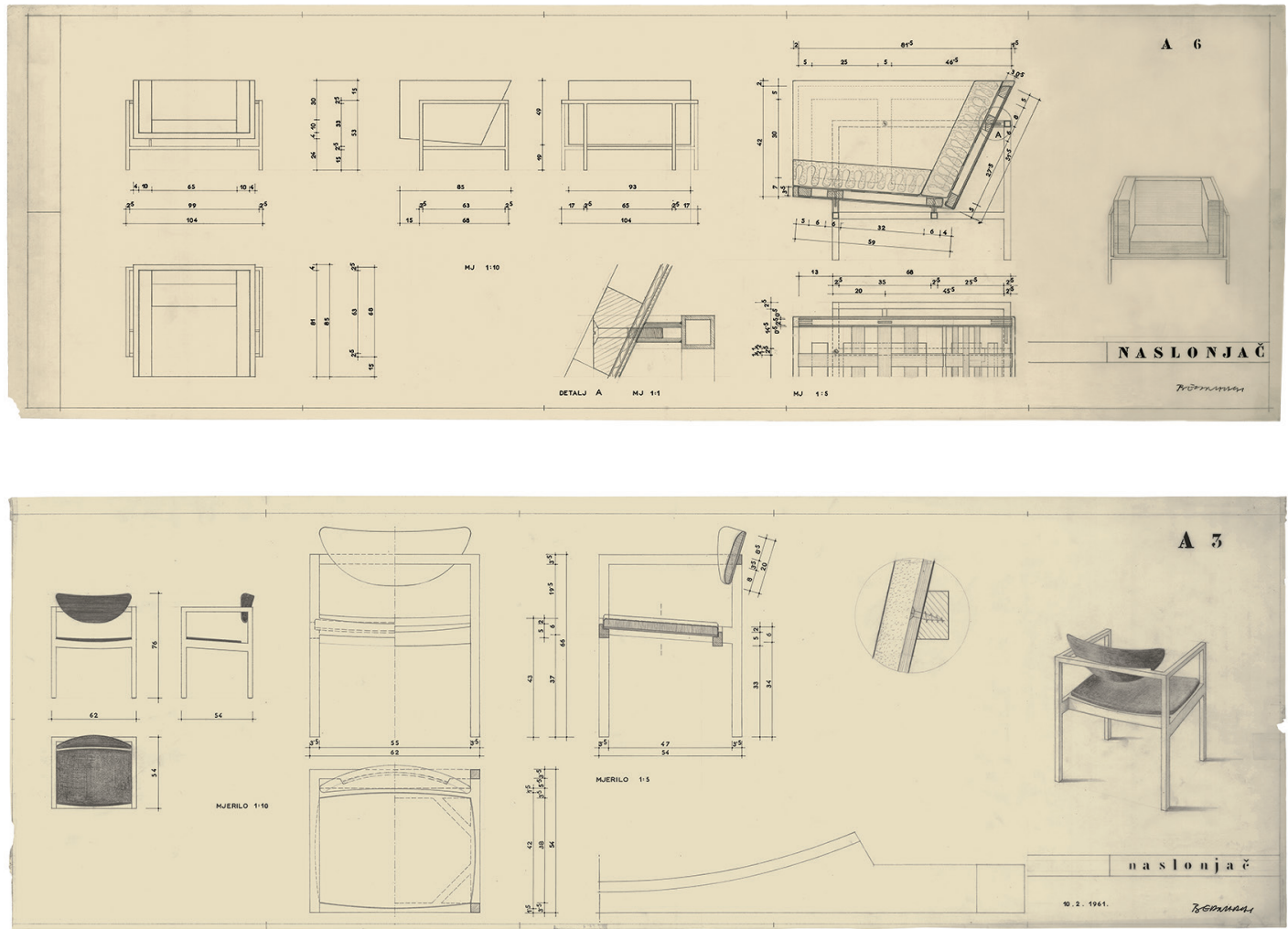

Slika 6

Bernardo Bernardi, naslonjač $\mathrm{A}_{3}$, paus/

olovka, I96I.

HMA HAZU, OAF BB

Slika 7

Bernardo Bernardi, naslonjač A4, I96I. HMA HAZU, OAF BB 
tom smislu zapažanje Alice Friedman, koja u Rietveldovu uređenju interijera za Truus Schroder ne primjećuje samo pročišćeni prostor u maniri pravca De Stijl, već više od toga. Prema njezinu mišljenju, to je mjesto koje donosi iskustvo modernog života: „(...) bilo je to mjesto na kojem se mogao iskusiti i raspraviti novi način života." ${ }^{13}$ Neposrednost iskustva, kao jedna od mogućnosti današnjeg upravljanja kulturnom baštinom, otvara niz mogućnosti: tako je Kratvænget I5-nekoć obiteljska kuća Finn Juhla na sjeveru Kopenhagena-otvorila vrata posjetiteljima 2008. godine kao dio muzeja Ordrupgaard. Komunicirajući kulturno-estetsku vrijednost organskog namještaja i osebujnog kolorita prostor je postao model (pre) nošenja kulturne memorije, jer ,jedna je stvar vidjeti slike, a sasvim druga biti tamo i osjećati prostranost i fizičku kvalitetu kuće i namještaja". ${ }^{14}$

\section{„Vremenske kapsule”- mikrokozmosi izgubljene cjeline}

Ipak, najsrodniji je primjer zagrebačkome Radničkom sveučilištu zasigurno Arne Jacobsenov SAs Royal Hotel, realiziran I96o. godine u središtu Kopenhagena. Za potrebe unutrašnjosti te zgrade, u obliku dvaju suprotstavljenih kubusa s ritmiziranim pročeljem u sivozelenom staklu, Jacobsen je oblikovao mobilijar mekih linija, stvarajući ambijentalnu sintezu geometrijskog i organskog krila kao što će to biti slučaj i kod zagrebačkog RANS-a. Prisutnost slobodnih formi čitljiva je već u ritmu nazivlja naslonjača: Dråben (stolac-kaplja / The Drop Chair), Svanen (stolac-labud / The Swan Chair), Agget (stolac-jaje / The Egg Chair), danas klasika svjetske dizajnerske baštine. ${ }^{15}$

Važna je poveznica dvaju srodnih prostora prisutnost preostalog namještaja in situ-s napomenom da je u kopenhaškom interijeru preostala tek jedna izvorna cjelina: apartman 6o6, kao svojevrsni mikrokozmos Jacobsenova antologijskog djela. Taj originalno sačuvan dio Michael Sheridan naziva „vremenskom kapsulom" (time-capsule) u kojoj je tematski kondenziran cijeli jedan zaboravljeni svijet ili riječima autora: „(...) izgubljeni svijet apstraktne forme i prirođenog iskustva, bio je to jedinstveni primjer dvadesetostoljetne skandinavske arhitekture i dizajna."16 Poput zagrebačkog RANS-a, i prostor SAS-ova doma obuhvatio je u duhu total-dizajna raspon od pročelja do interijera, ugrađenog i mobilnog namještaja, rasvjete i tekstila, pa sve do zastora i pribora za jelo. Danas, u malom mjerilu apartmana 606 kao zastupnika izgubljene cjeline, moguće je ponovno doživjeti izvorne vrijednosti boja, materijala i oblika tog antologijskog prostora.

Model revitalizacije pojedinačnih zona stoga je prikladan upravo za interijer moderne, čije značajke podrazumijevaju zajednički vizualni nazivnik dijelova i cjeline. Uz provedenu obnovu sačuvanog, važno je i poznavanje izvornih dispozicija mobilijara, čime se osigurava autentičnost komuniciranja vrijednosti nekadašnje cjeline. Saznanja o izvornom izgledu pouzdano pružaju arhivske fotografije, pa je tako u slučaju
I3 „(...) it was a place in which a new way of life could be discussed and experienced." [hrv. prev. ur.] Cit. prema: ALICE FRIEDMAN, Women and the Making of the Modern House, New York, I998., 73, izvorno u: MICHAEL WHITE, De Stijl and Dutch Modernism, Manchester / New York, 2003., I08..

I4 „(...) it is one thing to see pictures, but quite another to be there and feel the spaciousness and physical quality of the house and furniture" [hrv. prev. ur.] PER H. HANSEN, Finn Juhl and His House, København / Stuttgart, 20I4., I80.

I5 Jacobsenova serija danas je dio stalnog postava kopenhaškog Designmuseuma, kao što je Bernardijev naslonjač A4 uvršten u stalni postav zagrebačkog Muzeja za umjetnost i obrt.

I6 „.... lost world of abstract form and natural experience, that was unparalleled example of 2 oth-century Scandinavian architecture and design" [hrv. prev. ur.] MICHAEL SHERIDAN, Room 6o6. The SAS House and the Work of Arne Jacobsen, London / New York, 2003., 9 . 
Radničkog sveučilišta ${ }^{17}$-na tragu Sheridanovih „vremenskih kapsula"-moguće utvrditi nekoliko revitalizacijskih zona kao nositelja karakterističnih oblikovnih i sadržajnih značajki nekoć vrhunske atmosfere modernizma koja prožima taj prostor. Tako je reprezentativan ulazni hol markiran s nekoliko grupacija naslonjača za odmor i pripadnih staklenih stolića, longitudinalno raspoređenih duž kontinuirane staklene stijene kroz koju pritječe obilna svjetlost južnog patija, stapajući unutrašnji i vanjski prostor u jedno. Nadalje, danas devastiran i zaboravljen prostor nekadašnjeg Kluba-opremljen grupama atraktivnih A4-naslonjača, s pogledom prema današnjoj Sveučilišnoj aleji-sljedeća je referentna točka prostorne memorije (sl. 8) te izazov budućim obnovama. ${ }^{18}$ Naposljetku, arhivske fotografije dopuštaju uvid u nekadašnji prostor čitaonice i biblioteke, gdje u difuznoj atmosferi sjevernog krila-kao svojevrsni antipod Klubu-ispod kupola nadsvjetala, okrugli stol za čitanje periodike poput velike kružnice ocrtane ritmom A4-naslonjača markira prostor (sl. 9, Io).
I7 Po realizaciji zgrade, prostore interijera snimao je Željko Krčadinac, službeni fotograf Radničkog sveučilišta, kojem zahvaljujem na ustupanju fotografija za potrebe istraživanja.

I8 Valorizacija interijera i mobilijara kao jedinstvene cjeline zgrade te prijedlog modela revitalizacijskih zona navedenih cjelina argumentiraju se u: IVA CERAJ, IVANA HANIČAR BULJAN, RENATA MARGARETIĆ URLIĆ, Konzervatorska studija s idejnim prijedlogom prezentacije dijela zgrade Pučkog otvorenog učilišta, (stručna sur.)A. Kovačić, P. Mofardin, Institut za povijest umjetnosti, Zagreb, 20I7.

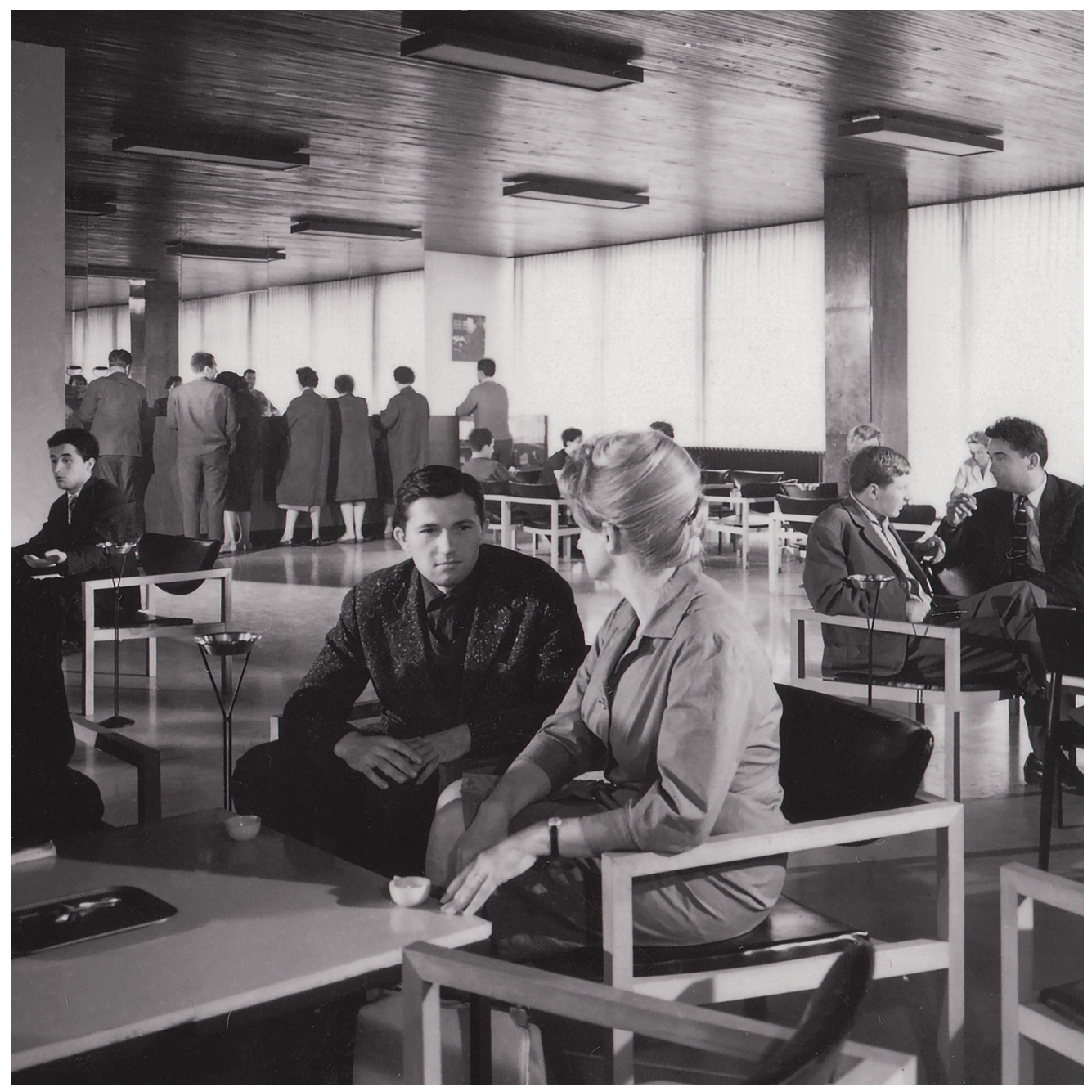

Slika 8

Klub na I. katu RS, I96I. foto: Ž. Krčadinac, Osobni foto-arhiv autora 


\section{Zaključak-prema stvaranju kulturnog identiteta}

Ovako uspostavljene referentne točke s izvorno disponiranim, autentičnim mobilijarom ${ }^{19}$ jesu „revitalizacijske zone”, odnosno model kojim se zagovara neposredno poznavanje prvih klasika hrvatskog dizajna u izvornom ambijentu kao mjestu generiranja znanja o sintezi svih umjetnosti. Novu osjetljivost za tu vrstu kulturnog nasljeđa moguće je razvijati samo njegovim poznavanjem, poradi čega zaštiti materijalne baštine valja priključiti i promicanje nematerijalne-koja de facto znači poznavanje moderniteta. Tu vrstu znanja moguće je komunicirati u formatima vodstva i digitalnih aplikacija, izložbi i monografskih naracija, a sve u svrhu razvijanja svijesti o vlastitim vrijednostima i kulturnom identitetu.

$\mathrm{U}$ tom smislu rezultati istraživanja dizajnerskog djela arhitekta Bernarda Bernardija kao primjera dizajnerske baštine zagrebačke moderne, priključuju se europskim tendencijama (re)valorizacije dizajnerskih opusa poslijeratnog razdoblja. ${ }^{20}$ Provedene etape istraživačkog rada, izložbena prezentacija i monografski prikaz te dalji prijedlozi novih modela zaštite nude metodološki legitimitet koji omogućuje utemeljenu uspostavu novog termina-klasik hrvatskog dizajna-kao priloga poznavanju kulturnih umrežavanja i poveznica u procesu mapiranja dizajnerske baštine europske moderne. ${ }^{21}$
I9 Faksimil u ovom slučaju nije relevantno rješenje, zbog lišenosti tzv. slojeva pamćenja.

20 Te tendencije prisutne su osobito $u$ nordijskim zemljama, gdje je u posljednje vrijeme održan niz retrospektivnih izložbi klasika dizajna tzv. „druge generacije"-Ilmari Tapiovaara (Designmuseum, Helsinki) ili Hans J. Wegner (Designmuseum, Kopenhagen), primjeri su (re)valoriziranih opusa u 2014. godini, monografski popraćenih rezultatima novih znanstvenih istraživanja.

2I Monografiju je, između ostalih, promovirao i Timo Rajakangas, veleposlanik Republike Finske u Republici Hrvatskoj, dok je izložbu otvorio Anders Christian Hougård, veleposlanik Kraljevine Danske u Republici Hrvatskoj (usp. bilj. 4 i 5). Zajednički predgovor monografiji potpisuju sva četiri veleposlanika nordijskih zemalja u Hrvatskoj, što je Bernardijevu dizajnerskom opusu potvrdilo mjesto na mapi europske dizajnerske baštine.

\section{(c) (i)}

Od muzejske zbirke do provedbe zaštite in situ-proces uspostave dizajnerske baštine zagrebačke moderne / Iva Ceraj / CC BY / 4.0

DoI: https://doi.org/Io.3I664/z4khpu.30
Slika 9 i ro

Čitaonica u prizemlju RS, I96I. foto: Ž. Krčadinac, Arhiv Knjižnice Pučkog otvorenog učilišta Zagreb

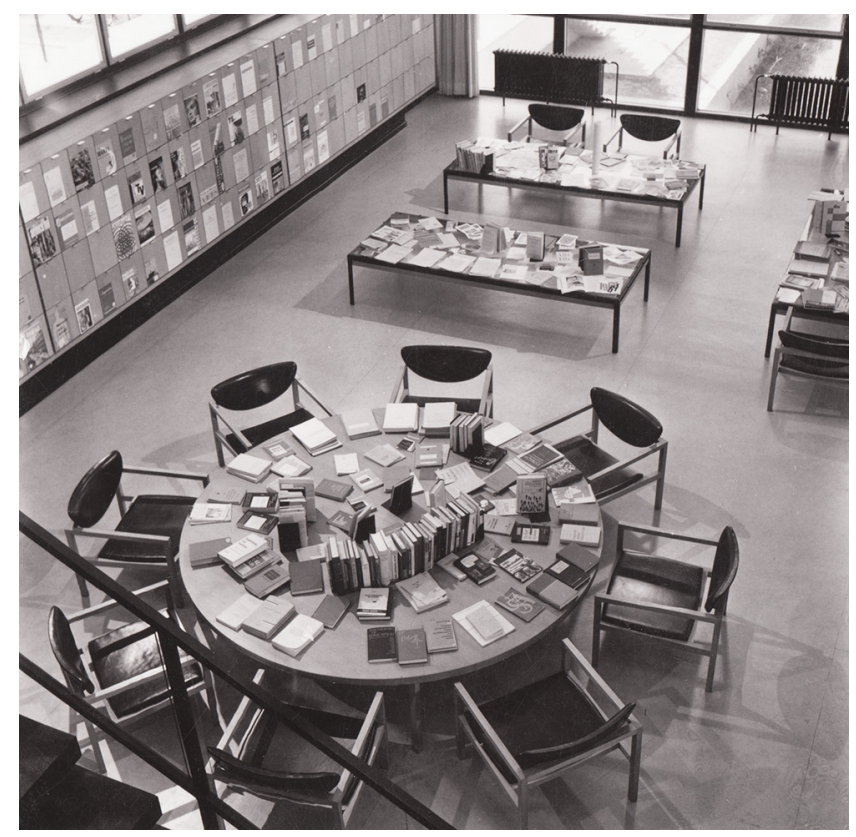

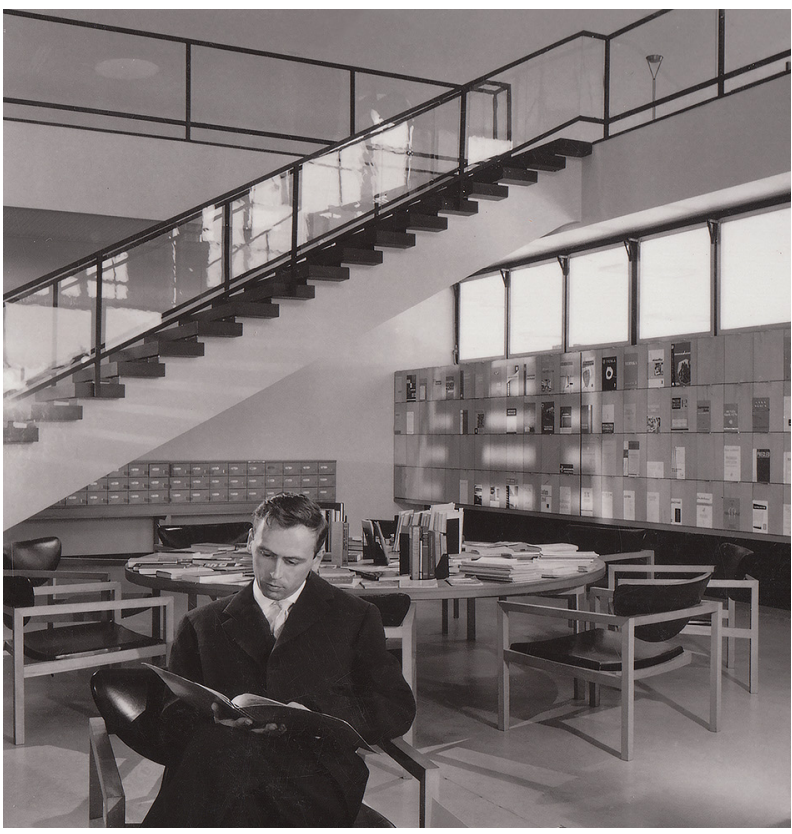

